\title{
Human Placental Lactogen: Studies of Its Acute Metabolic Effects and Disposition in Normal Man*
}

\author{
Paul Beck $\dagger$ and William H. Daughaday $\ddagger$ \\ (From the Division of Metabolism, Department of Medicine, Washington University School \\ of Medicine, St. Louis, Mo.)
}

\begin{abstract}
Summary. The acute metabolic effects and disposition of human placental lactogen (HPL) have been studied in 15 men and 8 women during continuous intravenous infusions. The mean plasma half-life, metabolic pool size, and turnover rate of HPL are comparable to the values previously reported for human growth hormone (HGH). From the data presented, we calculate that the placenta secretes approximately $290 \mathrm{mg}$ HPL daily at term.

After 12-hour infusions of HPL in physiologic amounts, impairment of glucose tolerance despite increased plasma insulin responses to glucose was observed in 7 of 8 subjects tested. However, HPL, unlike HGH, did not produce significant changes in blood glucose, plasma insulin, or plasma free fatty acid concentrations in fasting subjects before glucose administration or in carbohydrate tolerance or plasma insulin responses to glucose during 5-hour infusions. These findings are compatible with the thesis that HPL is a physiologic antagonist to insulin during pregnancy.
\end{abstract}

\section{Introduction}

The appearance in the plasma of pregnant women of a peptide, human placental lactogen, which cross-reacts immunologically with human growth hormone (1) and shares some of the biologic actions of growth hormone (2), has suggested that this material might induce metabolic changes in pregnancy. Pregnancy is associated with an antagonism to the hypoglycemic action of insulin $(3,4)$ which is comparable to that observed in acromegaly $(5,6)$ and to that which follows the administration of growth hormone ( 7 , 8). Experimental studies have indicated that

* Submitted for publication June 30, 1966; accepted September 28, 1966.

Supported by research grant AM 5105, National Institutes of Arthritis and Metabolic Diseases, and grant 5MO1-FR-36, Division of General Medical Sciences, National Institutes of Health.

† Trainee in metabolism, supported by U. S. Public Health Service grant AM 5027. Present address: University of Colorado School of Medicine, Denver, Colo.

$¥$ Address requests for reprints to Dr. William $\mathrm{H}$. Daughaday, Dept. of Medicine, Washington University School of Medicine, St. Louis, Mo. 63110.
HPL, like growth hormone, induces impaired glucose tolerance in cortisol-treated hypophysectomized rats (9), stimulates glucose oxidation to $\mathrm{CO}_{2}$ and incorporation into fat in the rat epididymal fat pad (10), and promotes lipolysis in isolated fat cells (11). Grumbach and associates (12) have observed a rise in the circulating free fatty acid levels of hypopituitary subjects after intramuscular injection of HPL. More recently, Samaan, Yen, Gonzalez, and Pearson (13) have reported deterioration of glucose metabolism in 2 hypophysectomized diabetic patients and an insulogenic response to a carbohydrate meal in 3 other subjects ( 2 hypopituitary) after prolonged intramuscular HPL treatment. Nevertheless, there have been no studies reported of the effects of exogenous HPL on carbohydrate and lipid metabolism in normal man.

In the present studies, the acute metabolic effects and the disposition of HPL were studied in man during prolonged intravenous infusions. Changes in blood glucose, plasma insulin, and plasma free fatty acid concentrations before glucose administration, in carbohydrate tolerance, 
TABLE I

Relative immunopotency of various preparations of human placenta lactogen $(H P L)^{*}$

\begin{tabular}{lc}
\hline \multicolumn{1}{c}{ Preparation } & \% reactivity \\
\hline HPL-T & 100 \\
Lederle Purified Placental & 28 \\
Protein (PPP) & 21 \\
Friesen Placenta Protein & 10 \\
Grumbach CGP 12-5 & 5 \\
HPL-B & 5
\end{tabular}

* All values expressed as relative immunoreactivity with specific anti-HPL antiserum per milligram of hormone protein.

and in plasma insulin responses to glucose were measured during and after HPL infusions. Under steady state conditions, the plasma half-life, volume of distribution, and turnover rate of exogenous HPL were determined.

\section{Methods}

Human placental lactogen. The various HPL preparations employed by investigators differ considerably in their immunologic activity [Table I and (14)], and there are, as yet, no standardized bioassays for HPL. Our current laboratory standard of reference (HPL-T) was prepared by DEAE chromatography of partially purified extracts (15) ; considerable further purification was obtained by isoelectric precipitation of DEAE purified material at $\mathrm{pH} 5.0$ followed by gel filtration of the immunoreactive supernate on Sephadex G-200 (16). This final product (Table I) was 4 times more immunoreactive than Lederle's Purified Placenta Protein (PPP) and 20 times more potent immunologically than HPL-B, the material previously employed as a standard in this laboratory (17); its lipolytic activity was twice that of PPP (16). All HPL values in this paper are expressed in terms of HPL-T, and any HPL data cited have been appropriately corrected. For example, the mean plasma HPL concentration at term [previously reported as $25 \mu \mathrm{g}$ per $\mathrm{ml}$ in terms of HPL-B(17)] is 1.15 $\mu \mathrm{g}$ per $\mathrm{ml}$. PPP ${ }^{1}$ was the HPL preparation used in our clinical studies.

Experimental procedure. The subjects (Table II) included 15 men and 8 women who were students, laboratory personnel, or Washington University Clinics patients whose ages ranged from 17 to 60 . Pituitary hypofunction was present in 2 men and 1 woman and was manifested by clinical signs of hypogonadism and by no increase in plasma somatotropin concentration after insulin-induced hypoglycemia. Deficiencies of adrenal and thyroid function were corrected by replacement therapy. Two patients (AB and FM) had diabetes mellitus, dis-

1 Lot no. 716223, kindly and generously supplied by Dr. Virgil A. Place, Lederle Laboratories, Pearl River, N. Y. covered during pregnancy or after a hysterectomy, which was controlled by diet alone. Of the remaining subjects, 2 were women who had undergone hysterectomy 6 and 24 months before testing, respectively, 4 were women with normal menstrual function 6 to 24 months after bilateral salpingectomy, and the rest were men who had no known history of endocrine disorders. Each subject was instructed to eat at least $200 \mathrm{~g}$ carbohydrate daily for 3 days before testing.

Five-hour intravenous infusions of $\mathrm{HPL}$ were given to 10 men and 4 women (Table II) during bed rest after an overnight fast and moderate activity. The HPL was delivered at a constant rate by an infusion pump in doses of 100 to $400 \mathrm{mg}$ of Lederle PPP in $100 \mathrm{ml}$ of saline over a 5-hour interval. Venous blood specimens (collected from indwelling polyethylene catheters at 10 and 1 minutes before; at 30 -minute intervals during; and at $10,20,30,60$, and 120 minutes after the infusion) were analyzed for blood glucose and plasma insulin, HPL, and FFA concentrations. In each subject, a 5-hour saline infusion was given in an identical way 1 to 7 days before the HPL infusion (in 2 subjects the HPL infusion preceded the saline infusion), and blood samples were collected at comparable time intervals for blood glucose and plasma insulin and FFA assay. Thus, each individual served as his own control.

TABLE II

Clinical data of subjects

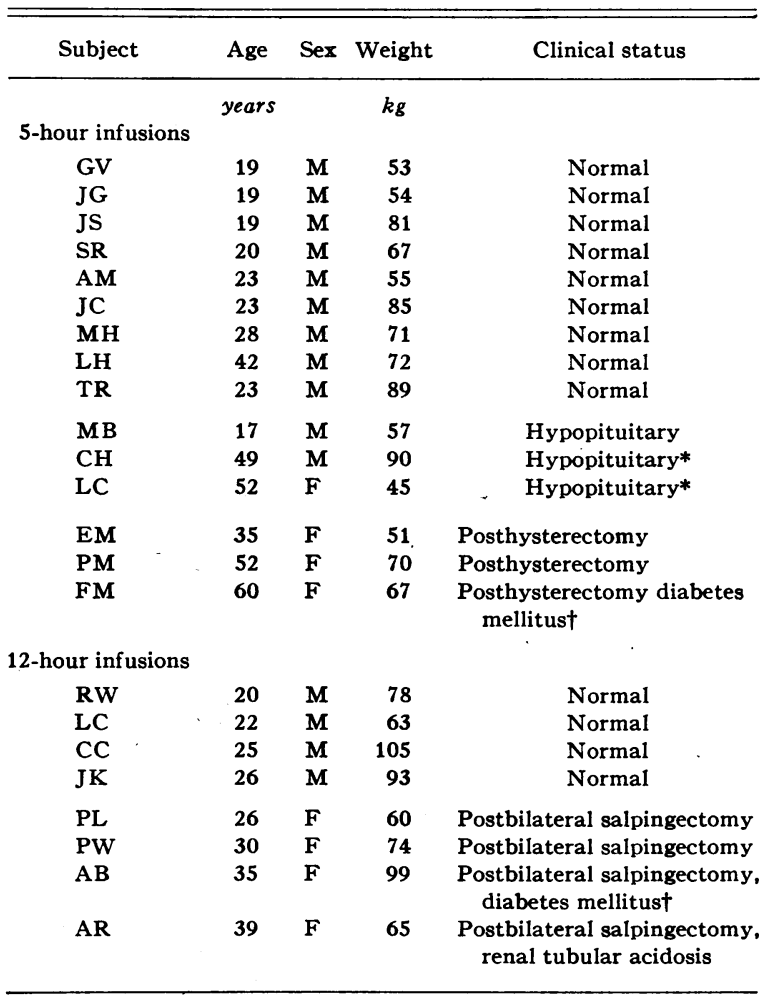

* Receiving cortisone acetate and thyroxine.
† Controlled by diet alone. 
TABLE III

Plasma half-life, metabolic pool size, and turnover rate of $H P L$ during constant rate intravenous infusions*

\begin{tabular}{lccccc}
\hline \hline Subject & $\begin{array}{c}\text { Rate of } \\
\text { infusion }\end{array}$ & $\begin{array}{c}\text { Plasma } \\
\text { t/ }\end{array}$ & \multicolumn{2}{c}{ Pool size, V } & $\begin{array}{c}\text { Turnover } \\
\text { rate, K }\end{array}$ \\
\hline & $\mu g / \min$ & $\min$ & $m l$ & \% body $w t$ & ml $/$ min \\
CH & 93 & 17.1 & 6,238 & 6.9 & 252 \\
JS & 93 & 26.5 & 14,310 & 17.7 & 373 \\
TR & 186 & 18.6 & 7,971 & 9.0 & 296 \\
MH & 186 & 13.4 & 2,661 & 3.8 & 137 \\
AM & 186 & 13.8 & 2,681 & 4.9 & 134 \\
JC & 373 & 23.1 & 6,600 & 7.8 & 197 \\
PM & 326 & 16.8 & 3,175 & 4.5 & 130 \\
FM & 336 & 20.2 & 4,041 & 6.0 & 138 \\
SR & 346 & 15.7 & 3,366 & 5.0 & 148 \\
JG & 273 & 21.3 & 5,135 & 9.5 & 166 \\
GV & 273 & 19.9 & 4,265 & 8.1 & 148 \\
EM & 273 & 15.9 & 2,650 & 5.2 & 115 \\
LC & 273 & 26.1 & 3,263 & 7.3 & 86 \\
MB & 373 & 16.5 & 3,148 & 5.5 & 132 \\
Mean & & 18.9 & 4,965 & 7.2 & 175 \\
SE & & \pm 1.0 & \pm 831 & \pm 0.9 & \pm 20.6 \\
& & & & & \\
\hline
\end{tabular}

* HPL was infused as Purified Placenta Protein (Lederle) in a constant volume $(0.33 \mathrm{ml}$ per minute) for 5 hours. All HPL concentrations are expressed in terms of our most potent laboratory standard. during the 30-minute period after the termination of the inf usion.

In 12 of the 14 subjects, oral (100 g) glucose tolerance tests were performed during the HPL and the control infusions. Glucose was ingested 2 hours after the beginning of each infusion. Oral $(100 \mathrm{~g})$ glucose tolerance tests were also performed after overnight 12-hour infusions of HPL in 4 men and 4 women (Table II). Lederle PPP was administered intravenously at the rate of $1.1 \mathrm{mg}$ per $\mathrm{kg}$ per hour. Control glucose tolerance tests were performed after an overnight saline infusion 1 day to 4 weeks before HPL treatment. Plasma cortisol concentrations were measured at the completion of each infusion.

The blood glucose concentrations were measured on blood specimens anticoagulated with sodium oxalate and collected in test tubes containing sodium fluoride. The plasma specimens were anticoagulated with heparin, separated promptly by centrifugation, and stored at $-14^{\circ} \mathrm{C}$ until the analyses were performed.

Analytical methods. Plasma HPL concentrations were determined by the double antibody radioimmunoassay previously described (17) with the following modifications: Guinea pig anti-HPL in a final dilution of $1: 28,000$ was used as the hormone-specific antiserum; HPL-T was used for iodination and as the reference standard. In later assays the hormone was iodinated with $\mathrm{Na}^{-125} \mathrm{I}^{2}$ rather than $\mathrm{Na}^{-131} \mathrm{I}$ because of the convenience of a longer lasting labeled hormone. Specific activities of $200 \mathrm{mc}$ per mg were obtained, and the immunologic reactivity of HPL- ${ }^{125} \mathrm{I}$ and HPL- ${ }^{131} \mathrm{I}$ was virtually identical for at least 3 months. In the assay system as modified, HGH in concentrations up to $6.4 \mathrm{mg}$ per tube did not interfere with the binding of labeled or unlabeled HPL by the guinea pig immune serum.

2 Isoserve Corp., Cambridge, Mass.
Plasma insulin concentration was determined by the double antibody method of Morgan and Lazarow (18). Plasma FFA was measured by the colorimetric method of Duncombe (19) with the Dole extraction procedure (20), blood glucose by ferricyanide reduction in an autoanalyzer, and plasma cortisol by the fluorimetric method of De Moor, Steeno, Raskin, and Hendrikx (21).

Calculations. The half-time of disappearance of HPL from the plasma was determined for each subject from a plot of the logarithm of his plasma HPL concentrations against time during the 30 -minute period after the termination of the HPL infusion.

The turnover rate of HPL $(\mathrm{K})$, in milliliters per minute, for each subject was determined under steady state conditions from the following formula (22): $K=R / c$, where $R=$ rate of infusion expressed as micrograms HPL per minute, and $c=$ plasma $\mathrm{HPL}$ concentration under steady state conditions in micrograms per milliliter.

Zilversmit (23) has shown that the metabolic pool size of a compound $(\mathrm{V})$ may be defined as $K / \mathbf{f}$ (where $\mathbf{f}$ is the fractional turnover rate of the compound) and that $\mathrm{f}=0.69 / \mathrm{t}_{\frac{1}{2}}$. Thus, if the half-time of disappearance of HPL from the metabolic pool is assumed to equal its half-life in plasma, the volume of distribution of the infused $\mathrm{HPL}$ is $\mathrm{V}=\left[\mathrm{K}\left(\mathrm{t}_{\frac{3}{3}}\right)\right] / 0.69$.

The plasma insulin response to the oral administration of glucose has been estimated by integrating the area beneath the curve of insulin concentrations (microunits per milliliter) plotted against time in minutes. The units of the integrated area are microunit-minutes.

\section{Results}

\section{HPL dynamics}

At rates of infusion ranging from 93 to $373 \mu \mathrm{g}$ HPL per minute (Table III), plasma HPL concentrations reached a plateau in each subject within 90 minutes (Figure 1) and remained con-

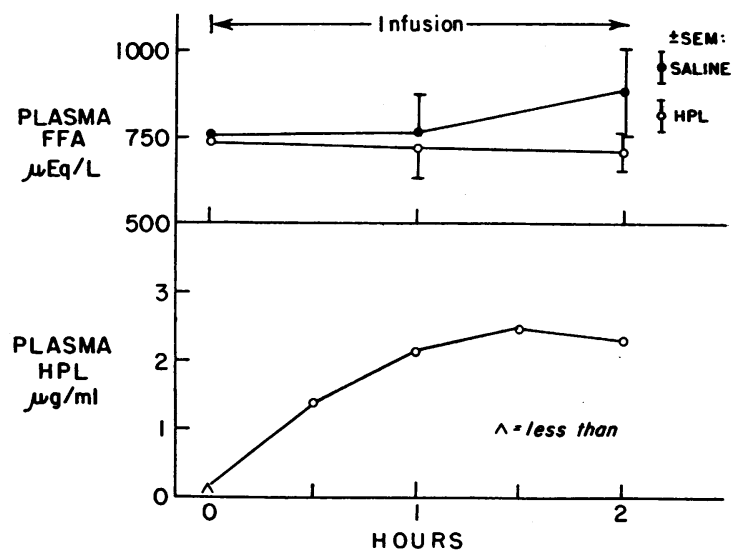

Fig. 1. Mean plasma FFA and human placental LACTOGEN (HPL) CONCENTRATIONS DURING CONSTANT RATE HPL INFUSIONS. Each point represents a mean value for 12 subjects. 


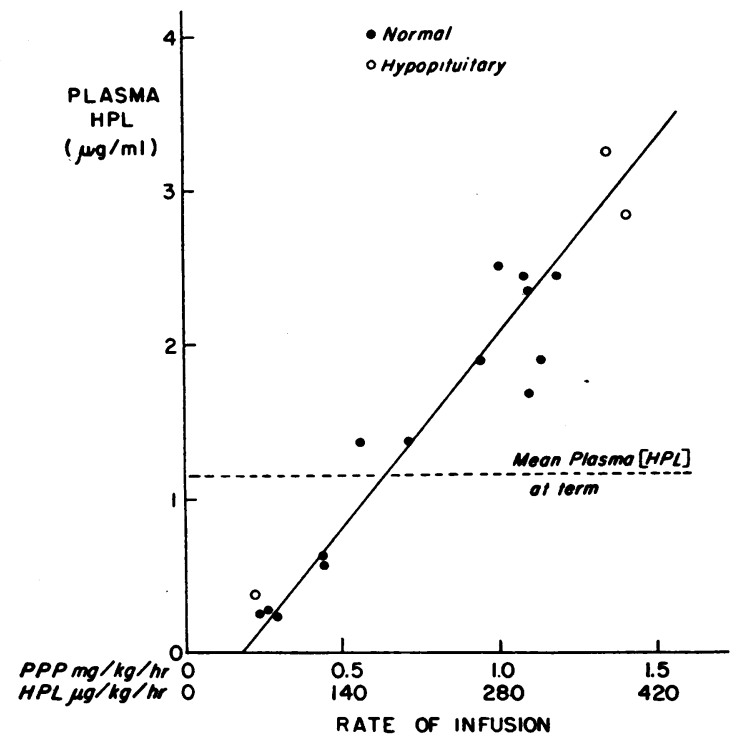

Fig. 2. Correlation of Plasma HPL concentraTIONS WITH RATE OF INFUSION DURING CONSTANT RATE HPL INFUSIons. Each point denotes the steady state plasma HPL concentration for an individual subject. PPP $=$ Lederle Purified Placenta Protein.

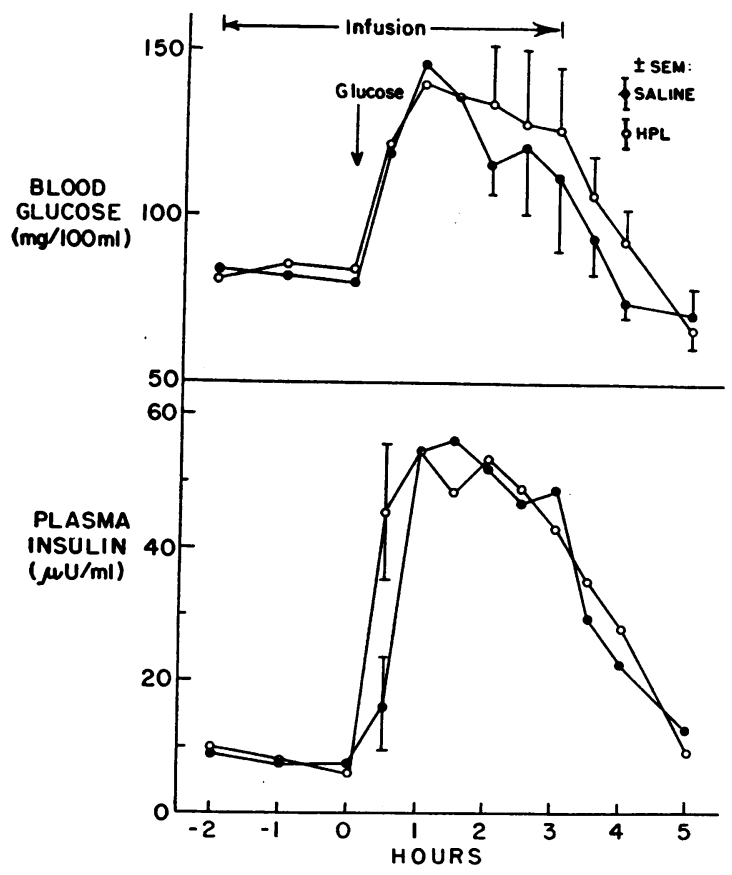

Fig. 3. Mean blood glucose and plasma insulin RESPONSES TO ORAL GLUCOSE DURING 5-HOUR CONSTANT RATE HPL infusions. Each subject received $100 \mathrm{~g}$ glucose 2 hours after beginning the infusion. Each point represents a mean value for 12 subjects. stant thereafter. As shown in Figure 2, the steady state concentration of HPL was directly proportional to the rate of HPL administration when corrected for body weight. Under steady state conditions, the mean ( \pm standard error) half-time of disappearance of exogenous HPL (PPP) from the plasma was $18.9 \pm 1.0$ minutes, the mean volume of distribution was $4,965 \pm 831$ $\mathrm{ml}$, and the mean turnover rate was $175 \pm 20.6$ $\mathrm{ml}$ per minute (Table III). There were no significant differences in any of the values obtained

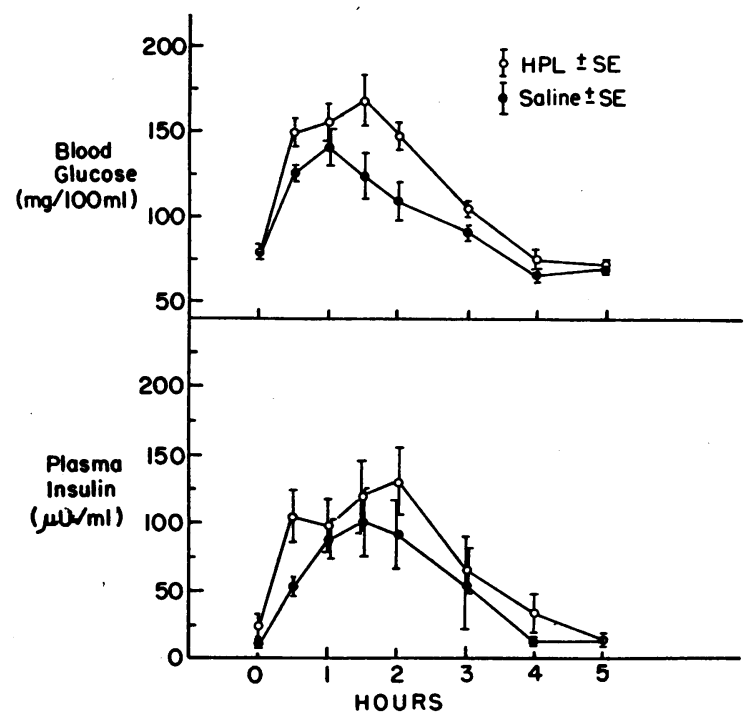

Fig. 4. MEAN BLOOd GLUCOSE AND PLASMa inSUlin RESPONSES TO ORAL GLUCOSE AFTER 12-HOUR INFUSIONS OF HPL. Each subject received $100 \mathrm{~g}$ glucose after overnight infusions of HPL and of saline.

between men and women, or between normal and hypopituitary or diabetic subjects.

\section{Metabolic studies}

Five-hour HPL infusions. The mean blood glucose and plasma insulin responses to glucose during the 5-hour HPL infusions are shown in Figure 3. Although the mean blood glucose concentrations of the human volunteers were higher during the 5-hour HPL infusions than during the control infusions at 2,3 , and 4 hours after glucose ingestion (Figure 3), these differences were not significant. Moreover, even when the blood glucose responses for each individual were compared before and after HPL treatment, there were no consistent changes in carbohydrate tolerance. 
TABLE IV

Changes in blood glucose and plasma insulin concentrations during oral (100 g) glucose tolerance tests after 12-hour HPL infusions*

\begin{tabular}{|c|c|c|c|c|c|c|c|c|c|}
\hline \multirow[b]{2}{*}{ Subject } & \multirow[b]{2}{*}{ Substance } & \multicolumn{8}{|c|}{ Time in hours } \\
\hline & & 0 & $\frac{1}{3}$ & 1 & $1 \frac{1}{2}$ & 2 & 3 & 4 & 5 \\
\hline \multirow[t]{2}{*}{ RW } & Glucose, $m g / 100 m l$ & $\begin{array}{c}(93) \\
66\end{array}$ & $\begin{array}{c}(137) \\
100\end{array}$ & $\begin{array}{c}(156) \\
113\end{array}$ & $\begin{array}{c}(116) \\
171\end{array}$ & $\begin{array}{l}(111) \\
142\end{array}$ & $\begin{array}{l}(86) \\
105\end{array}$ & $\begin{array}{c}(64) \\
76\end{array}$ & $\begin{array}{c}(75) \\
80\end{array}$ \\
\hline & Insulin, $\mu U / m l$ & $\begin{array}{c}(16) \\
10\end{array}$ & $\begin{array}{c}(64) \\
22)\end{array}$ & $\begin{array}{c}(84) \\
30\end{array}$ & $\begin{array}{c}(48) \\
52\end{array}$ & $\begin{array}{c}(54) \\
48\end{array}$ & $\begin{array}{c}(22) \\
20\end{array}$ & $\begin{array}{c}(10) \\
8\end{array}$ & $\begin{array}{c}(10) \\
4\end{array}$ \\
\hline \multirow[t]{2}{*}{ LC } & Glucose, $m g / 100 m l$ & $\begin{array}{c}(80) \\
93\end{array}$ & $\begin{array}{c}(141) \\
178\end{array}$ & $\begin{array}{c}(186) \\
205\end{array}$ & $\begin{array}{c}(154) \\
196\end{array}$ & $\begin{array}{c}(110) \\
136\end{array}$ & $\begin{array}{c}(115) \\
108\end{array}$ & $\begin{array}{l}(67) \\
114\end{array}$ & $\begin{array}{c}(67) \\
60\end{array}$ \\
\hline & Insulin, $\mu U / m l$ & $\begin{array}{l}(8) \\
74\end{array}$ & $\begin{array}{l}(18) \\
178\end{array}$ & $\begin{array}{l}(84) \\
136\end{array}$ & $\begin{array}{c}(124) \\
148\end{array}$ & $\begin{array}{c}(170) \\
216\end{array}$ & $\begin{array}{c}(108) \\
96\end{array}$ & $\begin{array}{l}(26) \\
104\end{array}$ & $\begin{array}{l}(28) \\
24\end{array}$ \\
\hline \multirow[t]{2}{*}{$\mathrm{CC}$} & Glucose, $m g / 100 m l$ & $\begin{array}{c}(80) \\
85\end{array}$ & $\begin{array}{c}(106) \\
162\end{array}$ & $\begin{array}{c}(136) \\
198\end{array}$ & $\begin{array}{c}(142) \\
182\end{array}$ & $\begin{array}{c}(142) \\
184\end{array}$ & $\begin{array}{l}(77) \\
130\end{array}$ & $\begin{array}{c}(68) \\
60\end{array}$ & $\begin{array}{c}(78) \\
70\end{array}$ \\
\hline & Insulin, $\mu U / m l$ & $\begin{array}{l}(8) \\
36\end{array}$ & $\begin{array}{l}(80) \\
152\end{array}$ & $\begin{array}{c}(136) \\
168\end{array}$ & $\begin{array}{c}(224) \\
176\end{array}$ & $\begin{array}{l}(200) \\
256\end{array}$ & $\begin{array}{l}(30) \\
120\end{array}$ & $\begin{array}{l}(8) \\
26\end{array}$ & $\begin{array}{l}(12) \\
14\end{array}$ \\
\hline \multirow[t]{2}{*}{$\mathrm{JK}$} & Glucose, $m g / 100 m l$ & $\begin{array}{c}(72) \\
67\end{array}$ & $\begin{array}{c}(136) \\
129\end{array}$ & $\begin{array}{c}(160) \\
110\end{array}$ & $\begin{array}{l}(90) \\
119\end{array}$ & $\begin{array}{c}(114) \\
125\end{array}$ & $\begin{array}{l}(92) \\
82\end{array}$ & $\begin{array}{c}(46) \\
44\end{array}$ & $\begin{array}{c}(62) \\
57\end{array}$ \\
\hline & Insulin, $\mu U / m l$ & $\begin{array}{l}(6) \\
8\end{array}$ & $\begin{array}{c}(30) \\
48\end{array}$ & $\begin{array}{c}(84) \\
38\end{array}$ & $\begin{array}{c}(40) \\
56\end{array}$ & $\begin{array}{l}(38) \\
84\end{array}$ & $\begin{array}{c}(30) \\
50\end{array}$ & $\begin{array}{c}(6) \\
8\end{array}$ & $\begin{array}{c}(0) \\
8\end{array}$ \\
\hline \multirow[t]{2}{*}{ PL } & Glucose, $m g / 100 m l$ & $\begin{array}{c}(72) \\
78\end{array}$ & $\begin{array}{c}(100) \\
201\end{array}$ & $\begin{array}{l}(58) \\
137\end{array}$ & $\begin{array}{l}(75) \\
118\end{array}$ & $\begin{array}{l}(60) \\
108\end{array}$ & $\begin{array}{l}(81) \\
102\end{array}$ & $\begin{array}{c}(68) \\
56\end{array}$ & $\begin{array}{c}(75) \\
71\end{array}$ \\
\hline & Insulin, $\mu U / m l$ & $\begin{array}{c}(2) \\
8\end{array}$ & $\begin{array}{l}(54) \\
190\end{array}$ & $\begin{array}{l}(24) \\
100\end{array}$ & $\begin{array}{c}(42) \\
36\end{array}$ & $\begin{array}{c}(22) \\
86\end{array}$ & $\begin{array}{c}(22) \\
42\end{array}$ & $\begin{array}{l}(8) \\
14\end{array}$ & $\begin{array}{l}(4) \\
14\end{array}$ \\
\hline \multirow[t]{2}{*}{ PW } & Glucose, $m g / 100 m l$ & $\begin{array}{l}(82) \\
88\end{array}$ & $\begin{array}{c}(142) \\
140\end{array}$ & $\begin{array}{c}(120) \\
122\end{array}$ & $\begin{array}{c}(109) \\
118\end{array}$ & $\begin{array}{c}(100) \\
128\end{array}$ & $\begin{array}{l}(74) \\
110\end{array}$ & $\begin{array}{l}(88) \\
85\end{array}$ & $\begin{array}{l}(77) \\
84\end{array}$ \\
\hline & Insulin, $\mu U / m l$ & $\begin{array}{l}(8) \\
12\end{array}$ & $\begin{array}{c}(62) \\
68\end{array}$ & $\begin{array}{l}(70) \\
52\end{array}$ & $\begin{array}{c}(40) \\
60\end{array}$ & $\begin{array}{c}(36) \\
62\end{array}$ & $\begin{array}{c}(12) \\
28\end{array}$ & $\begin{array}{l}(6) \\
10\end{array}$ & $\begin{array}{c}(6) \\
6\end{array}$ \\
\hline \multirow[t]{2}{*}{$\mathrm{AB}$} & Glucose, $m g / 100 m l$ & $\begin{array}{c}(89) \\
83\end{array}$ & $\begin{array}{c}(138) \\
160\end{array}$ & $\begin{array}{c}(183) \\
189\end{array}$ & $\begin{array}{l}(201) \\
225\end{array}$ & $\begin{array}{c}(163) \\
184\end{array}$ & $\begin{array}{c}(108) \\
120\end{array}$ & 95 & $\begin{array}{c}(57) \\
62\end{array}$ \\
\hline & Insulin, $\mu U / m l$ & $\begin{array}{c}(20) \\
38\end{array}$ & $\begin{array}{l}(88) \\
150\end{array}$ & $\begin{array}{c}(166) \\
178\end{array}$ & $\begin{array}{c}(186) \\
200\end{array}$ & $\begin{array}{c}(186) \\
194\end{array}$ & $\begin{array}{c}(147) \\
148\end{array}$ & 84 & $\begin{array}{c}(30) \\
32\end{array}$ \\
\hline \multirow[t]{2}{*}{ AR } & Glucose, $m g / 100 m l$ & $\begin{array}{c}(73) \\
71\end{array}$ & $\begin{array}{l}(114) \\
122\end{array}$ & $\begin{array}{c}(133) \\
171\end{array}$ & $\begin{array}{c}(109) \\
214\end{array}$ & $\begin{array}{l}(74) \\
169\end{array}$ & $\begin{array}{c}(86) \\
82\end{array}$ & $\begin{array}{c}(60) \\
77\end{array}$ & $\begin{array}{c}(62) \\
90\end{array}$ \\
\hline & Insulin, $\mu U / m l$ & $\begin{array}{c}(4) \\
8\end{array}$ & $\begin{array}{c}(30) \\
56\end{array}$ & $\begin{array}{c}(52) \\
80\end{array}$ & $\begin{array}{c}(104) \\
128\end{array}$ & $\begin{array}{c}(28) \\
94\end{array}$ & $\begin{array}{c}(64) \\
16\end{array}$ & $\begin{array}{c}(22) \\
12\end{array}$ & $\begin{array}{c}(10) \\
18\end{array}$ \\
\hline
\end{tabular}

* HPL was administered intravenously (1.1 mg per $\mathrm{kg}$ per hour) as Purified Placenta Protein. A control glucose tolerance test was performed in each subject after an overnight saline infusion. The values obtained during the control test are enclosed in parentheses.

During 2 hours of HPL infusion before glucose administration, there were no significant changes in the blood glucose, plasma insulin, or plasma FFA concentrations in the fasting subjects (Figures 1 and 3) despite the fact that in 9 of 12 subjects plasma HPL concentrations were greater than the mean plasma HPL concentration observed in pregnant women at term (1.15 $\mu \mathrm{g}$ per $\mathrm{ml}$ ) for at least 90 minutes (Figure 1).
Twelve-hour HPL infusions. To determine whether a longer administration of HPL was necessary before metabolic effects were observed, we gave overnight infusions of PPP (1.1 mg per $\mathrm{kg}$ per hour) to 4 men and 4 women. When the subjects were treated with HPL for 12 hours before glucose administration, significant changes in glucose tolerance and in plasma insulin responses to glucose were observed (Figure 4 and 
TABLE V

Integrated concentrations of plasma insulin during glucose tolerance tests after 12-hour infusions of $H P L^{*}$

\begin{tabular}{lccc}
\hline \hline & \multicolumn{3}{c}{ Insulin } \\
\cline { 2 - 4 } Subject & Before & After & $\Delta$ \\
\hline & \multicolumn{3}{c}{$\mu U / \min \times 10^{-\mathbf{z}}$} \\
RW & 10.7 & 7.2 & -3.5 \\
LC & 23.4 & 40.4 & +17.0 \\
CC & 24.9 & 36.1 & +11.2 \\
JK & 8.6 & 11.9 & +3.3 \\
PL & 6.5 & 18.6 & +12.1 \\
PW & 8.1 & 10.8 & +2.7 \\
AB & 36.8 & 40.0 & +3.2 \\
AR & 12.4 & 14.5 & +2.1 \\
& & Mean & +6.0 \\
& & $($ SD) & 45.2 \\
& & $t$ & $<.52$ \\
& & p & 0.05
\end{tabular}

* HPL was infused as Purified Placenta Protein $(1.1 \mathrm{mg}$ per $\mathrm{kg}$ per hour) overnight for 12 hours before glucose was administered. A control saline infusion was performed in each subject. Student's $t$ test for paired samples was used to determine the significance of the differences within individuals before and after HPL treatment

Table IV). Carbohydrate tolerance was decreased in 6 of the 8 subjects, and the insulin response was increased in 7 individuals after HPL administration. The mean ( \pm standard error) blood glucose concentration 2 hours after glucose ingestion was significantly higher $(\mathrm{p}<0.05)$ after overnight infusions with HPL $(147 \pm 8)$ than after the control infusion $(109 \pm 11)$. When analyzed by the $t$ test for paired samples (24), the mean increase in plasma insulin responses after HPL treatment $(6,000 \mu \mathrm{U}$-minutes $)$ was also significantly greater $(p<0.05)$ (Table V). This difference in the circulating insulin response might be attributed, in part, to the higher plasma insulin

TABLE VI

Plasma free fatty acid and cortisol concentrations after 12hour HPL infusions and after overnight saline infusions

\begin{tabular}{lccccc}
\hline \hline & \multicolumn{2}{c}{ FFA } & & \multicolumn{2}{c}{ Cortisol } \\
\cline { 2 - 3 } \cline { 5 - 6 } Subject & Control & HPL & & Control & HPL \\
\hline & \multicolumn{2}{c}{${ }^{\mu E q / L}$} & & & \multicolumn{2}{c}{$\mu / 100 \mathrm{ml}$} \\
RW & 420 & 716 & & 21 & 38 \\
LC & 995 & 647 & & 22 & 9 \\
CC & 426 & 477 & & 22 & 21 \\
JK & 592 & 443 & & 16 & 17 \\
PL & 367 & 900 & & 29 & 22 \\
PW & 513 & 621 & & 23 & 31 \\
AB & 591 & 595 & & 25 & 20 \\
AR & 464 & 505 & & 24 & 34 \\
Mean & 546.0 & 613.0 & & 22.8 & 24.0 \\
SE & \pm 78.0 & \pm 49.0 & \pm 1.2 & \pm 3.2 \\
& & & &
\end{tabular}

concentration observed in 3 of the fasting subjects subsequent to HPL administration; however, there were no significant differences in the mean blood glucose and plasma insulin concentrations in fasting subjects before and after HPL administration. Plasma insulin responses and changes in carbohydrate tolerance after HPL treatment were not significantly different in the men and women or in the normal and diabetic subjects. There were no consistent changes in plasma FFA or cortisol concentrations after the 12-hour HPL infusion in fasting subjects (Table VI).

\section{Discussion}

Resistance to the hypoglycemic action of insulin has been observed during pregnancy by many workers. Burt (3) reported that after the administration of insulin, blood glucose concentrations decline less in pregnant women than in subjects who are not pregnant. Kalkhoff and associates (4) observed that in normal women, plasma insulin responses to glucose and to tolbutamide are greater during pregnancy than during the puerperium even though glucose tolerance tests anteand postpartum are identical. As shown by Spellacy, Goetz, and co-workers (25-27), the magnitude of the insulin response to glucose increases progressively throughout gestation without deterioration in carbohydrate tolerance.

Many clinical and experimental studies have suggested that HPL may be a circulating insulin antagonist of pregnancy. HPL is present in the plasma of pregnant women in progressively increasing concentrations during gestation $(17,28)$ and disappears rapidly from the maternal circulation after delivery (17). These changes in circulating HPL levels coincide temporally with the increasing magnitude of the plasma insulin response to glucose administration in successive periods of pregnancy reported by Spellacy and co-workers (25-27) and with the rapid disappearance of resistance to the hypoglycemic action of insulin from all women in the puerperium (4, $27,29)$. The observations by Beck and Daughaday (9) that HPL-B impairs glucose tolerance in hypophysectomized rats and by Samaan and coworkers (13) that HPL has diabetogenic effects in hypophysectomized diabetic patients are consistent with these findings. 
In the present studies, impairment of peripheral glucose utilization despite increases in the plasma insulin responses to glucose was observed in normal human subjects after 12 -hour infusions with HPL. However, unlike HGH (8), HPL in 5hour infusions did not produce changes in glucose or FFA metabolism. Grumbach and co-workers (12) also noted a slower plasma FFA response to HPL administered intramuscularly than to $\mathrm{HGH}$ in hypopituitary subjects.

It does not appear likely that the contrainsulin effect observed after overnight HPL administration is mediated by HPL-induced release of $\mathrm{HGH}$ or ACTH into the peripheral circulation or by increases in extracellular FFA concentrations. Although neither $\mathrm{HGH}^{3}$ nor ACTH levels in plasma were measured directly, there were no significant changes in plasma FFA or cortisol concentrations (Table VI) after HPL treatment. Nevertheless, it is possible that HPL produced changes in intracellular FFA concentrations that led to impaired carbohydrate tolerance. Schonfeld and Kipnis (30) have recently observed that glucose transport and phosphorylation in isolated rat diaphragms correlate better with the intracellular pool size than with external FFA concentrations. An alternative explanation for the contrainsulin effect of HPL is provided by Josimovich, who found that HPL potentiates the action of $\mathrm{HGH}$ in rats by partially preventing hypoglycemia induced by insulin (31).

The possibility remains that the steroid hormones secreted by the placenta may affect glucose and insulin metabolism. Gershberg, Javier, and Hulse (32) have reported a high incidence of abnormal glucose tolerance tests among normal women taking norethynodrel and mestranol for contraception; however, the control population was not identical to the progestin-estrogen treated group. Impaired glucose tolerance was observed by Waine, Frieden, Caplan, and Cole (33) in 6 of 8 rheumatoid arthritis patients treated with large amounts of the same ovulatory suppressant for 8 to 300 days. More recently, Spellacy and Carlson (34) reported increased plasma insulin and blood glucose responses to intravenous glucose

\footnotetext{
${ }^{3}$ Because of the large amounts of HPL, which crossreacts immunologically with $\mathrm{HGH}$, in the plasma of these subjects, it was not possible to measure HGH by immunoassay.
}

in normal women after norethynodrel-mestranol treatment for 19 days. These results suggest the possibility that the increased plasma concentrations of estrogens (35) and progesterone (36) during pregnancy might also affect peripheral glucose utilization.

The mean plasma half-life, metabolic pool size, and turnover rate of HPL (Table III) are comparable to the values previously estimated for $\mathrm{HGH}$ (37). Because the mean volume of distribution of HPL ( $7.2 \%$ of body weight) is larger than the plasma volume, HPL may be present in interstitial fluid to a limited extent.

Based on a mean plasma HPL concentration at term of $1.15 \mu \mathrm{g}$ per $\mathrm{ml}$ and a daily HPL turnover rate of $175 \mathrm{ml}$ per minute, the synthesis of HPL by the placenta at term is calculated to be $290 \mathrm{mg}$ per day; this value is in agreement with the production rate for endogenous HPL previously estimated by Kaplan and Grumbach (14) expressed in terms of HPL-T. This quantity is much larger than the amount of HPL excreted in the urine at term $(<100 \mu \mathrm{g}$ per day) (13) and demonstrates that HPL is catabolized rapidly in the body tissues.

The quantity of HPL administered to our subjects during the overnight infusions ranged from 230 to $386 \mathrm{mg}$ (in terms of HPL-T) and was within physiologic limits. With HPL administered at the rate of $300 \mu \mathrm{g}$ per $\mathrm{kg}$ per hour, the plasma concentration obtained during each HPL infusion was approximately $2.3 \mu \mathrm{g}$ per $\mathrm{ml}$, a value within the range observed during the last month of gestation. These data further support the hypothesis that HPL is a significant physiologic antagonist of insulin during pregnancy.

\section{References}

1. Josimovich, J. B., and J. A. MacLaren. Presence in the human placenta and term serum of a highly lactogenic substance immunologically related to pituitary growth hormone. Endocrinology 1962, 71, 209.

2. Josimovich, J. B., and B. L. Brande. Chemical properties and biologic effects of human placental lactogen (HPL). Trans. N. Y. Acad. Sci. 1964, 27, 161.

3. Burt, R. L. Peripheral utilization of glucose in pregnancy. III. Insulin tolerance. Obstet. and Gynec. 1956, 7, 658.

4. Kalkhoff, R., D. S. Schalch, J. L. Walker, P. Beck, D. M. Kipnis, and W. H. Daughaday. Diabetogenic 
factors associated with pregnancy. Trans. Ass. Amer. Phycns 1964, 77, 270.

5. Fraser, R., G. F. Joplin, L. H. Opie, and D. Rabinowitz. The augmented insulin tolerance test for detecting insulin resistance. J. Endocr. 1962, 25, 299.

6. Beck, P., D. S. Schalch, M. L. Parker, D. M. Kipnis, and W. H. Daughaday. Correlative changes of growth hormone and insulin concentrations with metabolic abnormalities in acromegaly. J. Lab. clin. Med. 1965, 66, 366.

7. Luft, R., and E. Cerasi. Effect of human growth hormone on insulin production in panhypopituitarism. Lancet 1964, 2, 124.

8. Kipnis, D. M., and M. F. Stein. Insulin antagonism: fundamental considerations. Ciba Foundation Colloquia on Endocrinology 1964, 15, 156.

9. Beck, P., and W. H. Daughaday in Daughaday, W. H., and D. M. Kipnis. The growth-promoting and anti-insulin actions of somatotropin. Recent Progr. Hormone Res. 1966 22, 49.

10. Friesen, H. Purification of a placental factor with immunological and chemical similarity to human growth hormone. Endocrinology 1965, 76, 369.

11. Turtle, J. R., G. Littleton, and D. M. Kipnis. Lipolytic action of human placental lactogen on isolated fat cells. Clin. Res. 1966, 14, 289.

12. Grumbach, M. M., S. L. Kaplan, C. L. Abrams, J. J. Bell, and E. A. Conte. Plasma free fatty acid response to the administration of chorionic "growth hormone-prolactin." J. clin. Endocr. 1966, 26, 478.

13. Samaan, N., S. C. C. Yen, D. Gonzalez, and O. H. Pearson. Metabolic effects of placental lactogen (HPL) in man. Program of the Forty-eighth Meeting, The Endocrine Society, 1966, p. 84.

14. Kaplan, S. L., and M. M. Grumbach. Serum chorionic "growth hormone-prolactin" and serum pituitary growth hormone in mother and fetus at term. J. clin. Endocr. 1965, 25, 1370.

15. Cohen, H., M. M. Grumbach, and S. L. Kaplan. Preparation of human chorionic "growth hormoneprolactin." Proc. Soc. exp. Biol. (N. Y.) 1964, $117,438$.

16. Turtle, J. R., P. Beck, and W. H. Daughaday. Purification of human placental lactogen. Endocrinology 1966, 79, 187.

17. Beck, P., M. L. Parker, and W. H. Daughaday. Radioimmunologic measurement of human placental lactogen in plasma by a double antibody method during normal and diabetic pregnancies. J. clin. Endocr. 1965, 25, 1457.

18. Morgan, C. R., and A. Lazarow. Immunoassay of insulin: two antibody system. Plasma insulin levels of normal, subdiabetic and diabetic rats. Diabetes $1963,12,115$.

19. Duncombe, W. G. The colorimetric micro-determination of long-chain fatty acids. Biochem. J. 1963, 88, 7.

20. Dole, V. P. A relation between non-esterified fatty acids in plasma and the metabolism of glucose. J. clin. Invest. 1956, 35, 150.
21. De Moor, P., O. Steeno, M. Raskin, and A. Hendrikx. Fluorimetric determination of free plasma 11-hydroxycorticosteroids in man. Acta endocr. (Kbh.) 1960, 33, 297.

22. Tait, J. F., S. A. S. Tait, B. Little, and K. R. Laumas. The disappearance of $7-\mathrm{H}^{3}-d$-aldosterone in the plasma of normal subjects. J. clin. Invest. 1961, 40, 72.

23. Zilversmit, D. B. The design and analysis of isotope experiments. Amer. J. Med. 1960, 29, 832.

24. Worcester, J. The statistical method. New Engl. J. Med. 1966, 274, 27.

25. Spellacy, W. N., F. C. Goetz, B. Z. Greenberg, and J. Ells. Plasma insulin in normal "early" pregnancy. Obstet. and Gynec. 1965, 25, 862.

26. Spellacy, W. N., F. C. Goetz, B. Z. Greenberg, and J. Ells. Plasma insulin in normal midpregnancy. Amer. J. Obstet. Gynec. 1965, 92, 11.

27. Spellacy, W. N., and F. C. Goetz. Plasma insulin in normal late pregnancy. New Engl. J. Med. 1963, 268, 988.

28. Kaplan, S. L., and M. M. Grumbach. Immunoassay for human chorionic "growth hormone-prolactin" in serum and urine. Science 1965, 147, 751.

29. Bleicher, S. J., J. B. O'Sullivan, and N. B. Freinkel. Carbohydrate metabolism in pregnancy. V. The interrelationships of glucose, insulin and free fatty acids in late pregnancy and post partum. New Engl. J. Med. 1964, 271, 866.

30. Schonfeld, G., and D. M. Kipnis. Studies of extracellular and tissue fatty acid pools and glucose metabolism in striated muscle. $\mathrm{J}$. clin. Invest. 1966, 45, 1071.

31. Josimovich, J. B. Potentiation of somatotrophic and diabetogenic effects of growth hormone by human placental lactogen (HPL). Endocrinology 1966, 78, 707.

32. Gershberg, H., Z. Javier, and M. Hulse. Glucose tolerance in women receiving an ovulatory suppressant. Diabetes 1964, 13, 378 .

33. Waine, H., E. H. Frieden, H. I. Caplan, and T. Cole. Metabolic effects of Enovid in rheumatoid patients. Arthr. and Rheum. 1963, 6, 796.

34. Spellacy, W. N., and K. L. Carlson. Plasma insulin and blood glucose levels in patients taking oral contraceptives. A preliminary report of a prospective study. Amer. J. Obstet. Gynec. 1966, 95, 474.

35. Roy, E. J., and R. Mackay. The concentration of oestrogens in blood during pregnancy. J. Obstet. Gynaec. Brit. Cwlth 1962, 69, 13.

36. Van der Molen, H. J. Determination of plasma progesterone during pregnancy. Clin. chim. Acta 1963, 8, 943.

37. Parker, M. L., R. D. Utiger, and W. H. Daughaday. Studies on human growth hormone. II. The physiological disposition and metabolic fate of human growth hormone in man. J. clin. Invest. 1962, 41, 262. 